Article

\title{
Five-Year Development Plans of Renewable Energy Policies in Iran: A Content Analysis
}

\author{
Somayeh Dehhaghi ${ }^{1}$, Shahla Choobchian ${ }^{1, * \mathbb{D}}$, Barat Ghobadian ${ }^{2}$, Homayon Farhadian ${ }^{1}$, Ants-Hannes Viira ${ }^{3}$, \\ Horatiu Ioan Stefanie ${ }^{4}$, Steven Van Passel ${ }^{5}$ (D) and Hossein Azadi ${ }^{6,7}$
}

1 Department of Agricultural Extension and Education, Tarbiat Modares University, Tehran 14115-111, Iran; s.dehhaghi@modares.ac.ir (S.D.); h.farhadian@modares.ac.ir (H.F.)

2 Department of Mechanics of Biosystems Engineering, Tarbiat Modares University, Tehran 14115-111, Iran; ghobadib@modares.ac.ir

3 Chair of Rural Economics, Estonian University of Life Sciences, 51006 Tartu, Estonia; ants-hannes.viira@emu.ee

4 Faculty of Environmental Science and Engineering, Babeş-Bolyai University, 400084 Cluj-Napoca, Romania; horatiu.stefanie@ubbcluj.ro

5 Department of Engineering Management, University of Antwerp, 2000 Antwerp, Belgium; Steven.VanPassel@uantwerpen.be

6 Department of Geography, Ghent University, 9000 Ghent, Belgium; hossein.azadi@ugent.be

7 Department of Economics and Rural Development, Gembloux Agro-Bio Tech, University of Liège, 5030 Gembloux, Belgium

* Correspondence: shchoobchian@modares.ac.ir; Tel.: +98-214-829-2329

check for

updates

Citation: Dehhaghi, S.; Choobchian,

S.; Ghobadian, B.; Farhadian, H.;

Viira, A.-H.; Stefanie, H.I.; Van Passel,

S.; Azadi, H. Five-Year Development

Plans of Renewable Energy Policies

in Iran: A Content Analysis.

Sustainability 2022, 14, 1501. https://

doi.org/10.3390/su14031501

Academic Editor: George

Kyriakarakos

Received: 1 December 2021

Accepted: 17 January 2022

Published: 27 January 2022

Publisher's Note: MDPI stays neutral with regard to jurisdictional claims in published maps and institutional affiliations.

Copyright: (c) 2022 by the authors. Licensee MDPI, Basel, Switzerland. This article is an open access article distributed under the terms and conditions of the Creative Commons Attribution (CC BY) license (https:/ / creativecommons.org/licenses/by/ $4.0 /)$.

\begin{abstract}
Renewable energy (RE) policies can play an effective role in the development of renewable resources. The main goal of this paper was to conduct a content analysis on RE development policies in Iran's five-year National Development Plan (NDP) by investigating upstream national documents. To achieve the goal, 29 upstream documents related to RE were identified and analyzed through a systematic literature review. Then, a qualitative content analysis was applied to analyze the documents. The results showed that Iran's current RE policies need to be reviewed, reformed, and strengthened. For example, lack of sufficient attention to renewable heat and fuel was one of the deficiencies of RE policies in Iran's five-year NDP. The decentralization of policymaking in the unified organization was also one of the weaknesses in the policymaking process of the RE. Iran can develop sustainable and clean RE policies by using sources such as solar, wind, geothermal, hydropower, wave, and tidal power. The paper concludes that, although RE policies have the potential for development in Iran due to environmental, social, and economic advantages, they could face some infrastructural, managerial, socio-cultural, and economic challenges. Accordingly, effective and innovative policymaking is required to meet such challenges.
\end{abstract}

Keywords: energy; policymaking; energy policy; fossil fuel; quantitative analysis; renewable energy development

\section{Introduction}

Today, ensuring a reliable and sustainable supply of energy as well as an appropriate demand market is a crucial concern of any government for comprehensive development. This is only possible with energy policymaking [1-3] at all levels of national governments and at the international level. Governments face challenges such as fluctuating fossil fuel prices, rising global energy demands, uncertainty in oil and natural gas resources [4] due to geopolitical concerns, and global warming [5]. Thus, energy has become an important economic challenge [6], and it has attracted the attention of policymakers $[7,8]$. Hence, policymakers have begun to focus on adapting the existing policies to continuous changes $[9,10]$. Energy policy is an important tool for influencing on societies' economic, political, and social activities $[11,12]$. Energy policies are the basis for the use of renewable energy (RE), 
and policy frameworks are the most appropriate tools to support the establishment of this type of energy in different contexts [10]. The RE policy is a new topic in the history of science and it is not more than half a century old [12].

In Iran, the government has been seeking to use renewable resources for years. Unfortunately, the share of renewables in Iran's energy plan is still very small and, so far, only $823 \mathrm{MW}$ of electricity has been generated through RE in Iranian power plants [13]. In 2018 (1397 Persian year), the country's renewable power plants produced 124.21 MW of solar energy and 12.5 MW of wind energy [14]. Furthermore, 21 new power plants with a total capacity of $85.136 \mathrm{MW}$ were established [15]. However, these measures are far from the vision of the sixth 5-year National Development Plan. In Iran's sixth 5-year National Development Plan (NDP), as part of a 30-year plan by 2050 (1429 Persian year), the growth in the share of renewable resources is targeted to be up to $5000 \mathrm{MW}$ [16]. While all countries are trying to accelerate and facilitate the use of RE through appropriate policies, Iran is no exception and has been following this path for years $[17,18]$. This is much more important for Iran due to fossil fuel resources limitation, high annual growth of energy consumption in Iran, and Iran's egression from the oil exporters group at the end of the present century that will affect the country's development process [19].

In 2017 (1397 Persian year), the Iranian government had planned to increase its total electricity production capacity by $5 \%$ or close to $44 \mathrm{GW}$ by 2021 (1400 Persian year) $[15,20]$. Aryanpur et al. [21] have stated that Iran intends to increase its share of RE to $32 \%$ by 2050 (1429 Persian year). This not only allows for the use of an alternate solution in other applications with greater economic benefits, but it also makes participation easier. Improving air quality in large cities with the help of wind energy is another RE development program in Iran [22]. The establishment of an RE program in Iran can help the country achieve its energy security, independence, and future climate goals, as well as turning significant energy supply crises into opportunities for business interests, technology research, exports, and job creation [21]. Iran's economy can be planned based on known and predictable electricity costs in the future because it is supplied from domestic sources and is free of any security, administrative, economic, and environmental challenges associated with oil and gas $[15,23]$.

Appropriate steps must be made to maintain the sustainability and continuity of Iran's worldwide presence in order to meet international responsibilities, particularly the Paris Agreement, and to safeguard the country's economic future, which is inextricably linked to energy [20]. Despite its enormous potential for RE generation, RE's contribution to Iran's energy basket is now insufficient [24]. Ineffective policies (such as a lack of innovative initiatives, a lack of improved public services, the systemic and conventional structure of public policy, and a lack of financial resources) are among the reasons for the failure to use RE [21]. Iran has adopted policies in five-year development plans and related upstream national documents, and varieties of programs have been designed to achieve those goals [23]. In this way, understanding all aspects of the key issue is essential to adopt the right policy. It is necessary to identify and address the shortcomings of these policies as well as their strengths, but the types and dimensions of policies that have been adopted so far are unknown, and the weakness of studies in identifying renewable policies in Iran is evident. As a result, a systematic scientific understanding of the country's RE sector's planning and policymaking structure, adaptation of existing policies to the needs of society, appropriate types of policies, and appropriate mechanisms for RE development appear to be required. To achieve this framework, analyzing the plans and upstream national documents related to renewable policies will play an important role. These documents are policies, laws, and regulations designed and approved for the development of RE by various governments of Iran over the years and are considered as a roadmap to access a variety of RE resources. The oldest versions of these documents have been drafted in 1973 (1352 Persian year), and the newest ones were approved in 2017 (1396 Persian year).

In 2017, the RE production sector mainly included 53.88 MW of wind energy, $13.56 \mathrm{MW}$ of biomass energy, and $0.51 \mathrm{MW}$ of solar energy and as mentioned above, in 2018, the total 
installed capacity was increased to $823 \mathrm{MW}$. However, only $0.2 \%$ of Iran's energy is still produced from renewable sources [25]. Iran's goal, according to the sixth NDP (2017-2021 and 1397-1400 Persian year), is to generate $\%$ of its electricity, with the goal of increasing the share of RE resources which have not materialized yet due to recent droughts and despite Iranian sanctions [18]. Moreover, reports from the Energy Efficiency Organization indicate a delay in the implementation of this program. The development of RE resources can be considered a positive step according to the current program of Iran, and more active and more important issues such as biomass should be adopted $[15,26]$.

Many studies $[27,28]$ on RE policies have been conducted, but the majority of these studies are quantitative in nature and focus on the investigation and performance of one or more policies. Furthermore, most studies have focused solely on the development of renewable electricity $[29,30]$ or biofuels $[31,32]$ or have examined policies in the industry [33] and transportation sectors [34]. However, in order to identify a country's strengths and weaknesses, its RE development policies must be analyzed and investigated. Huge potential resources remain undiscovered and underused due to lack of awareness and ineffective government policies. By prioritizing the most suitable potential sources or alternatives, the results of this study can help stakeholders (policymakers, planners, investors, etc.) to identify gaps in the development of RE in Iran and seek to address them. Finally, evaluating the pros and cons of policy recommendations for each source of RE can provide a final guideline for an RE policy for long-term development at the national level. In addition, highlighting the state and achievement in the future of each RE plan will benefit private investors, developers, and consumers. As a result, this study seeks to examine RE policies in Iran's five-year NDP and other upstream national documents. According to this purpose, this article attempts to provide answers to the following research questions:

1. What are Iran's RE policies for the five-year NDP?

2. What are the most important factors influencing RE policies development?

3. What types of RE policies have been overlooked by policymakers?

4. Are the policies generic or do they take into account details such as the region's potential, facilities, geographical conditions, and so on?

\section{Theoretical Framework}

All countries have tended to use RE to meet their energy needs. To this end, the RE policies implemented in these countries can play a sustainable and effective role in the development of renewable industries [27]. The RE industry has a bright future ahead of it, with numerous job opportunities and opportunities to invest [5]. According to research, more than $70 \%$ of patents for RE technologies have no market value [5]. This means that there are barriers to the development of RE [27]. However, RE has a significant and positive effect on economic well-being [35]. Many countries have adopted different policies and invested heavily to develop this kind of energy [28].

Guzowski and Recalde [36] believe that most countries with a high share of RE have achieved this success through energy policies. An example of a successful action in some countries such as Germany could be a guideline to pave the way for RE policies. In policymaking, government intervention as a central regulator is constant [37]. The path of renewables development without government support will be difficult. For this reason, governments prepare supportive policy packages for the development of RE and have included the RE technologies application and the strengthening of energy infrastructures in their working plan [38,39]. According to Stokes [40], designing and implementing RE policies include political decisions and performers. It is a difficult political task to adopt and implement an ambitious policy of RE. Factors that affect the initial success of RE policy may not be enough to advance a policy during a difficult implementation period. Policymakers also direct opposing and frequently contradictory forces when preparing ambitious RE policies. It is also true when high-level support for a policy does not necessarily lead to widespread popular support, especially for a local establishment. However, Horschig and Thrän [41] argued that increasing the share of RE often faces sustainability challenges, and 
despite these efforts, there is a gap between the achievements and what was targeted [5]. In addition, Gielen et al. [42] stated that it is necessary to create policies and regulatory frameworks. Shrimali et al. [43], using financial models, investigated India's RE policies effectiveness at the federal level. They noted that debt-related policies are among the most important cost-effective ways in the long term. In another study, Mamat et al. [44] analyzed the government's policies in Southeast Asia to establish RE sources. Bulut and Muratoglu [45] analyzed RE growth in Turkey. They stated that although Turkey has great potential in terms of RE, it has not yet begun to utilize it. However, Turkey has many motives to utilize RE in the near future. Schmid [3], based on his study on RE policies in India, noted that state-level policies, financial incentives, and greater private sector participation played an important role in developing the installed capacity of RE in nine states. Another study by Argentiero et al. [46] on RE sources policies in the Euro area found that carbon tax is not high enough to be a stimulus for investing in renewable technologies. In order to make RE competitive in the electricity market, public support is essential through carbon taxation, public subsidies, and etc. Technology-oriented policies are more appropriate than demand-oriented policies. Carley et al. [5], in a study on photovoltaic policies in Iran, concluded that policies to support photovoltaic technology are similar in all regions, and the government needs to differentiate between different regions in formulating new policies with different potentials [5]. Aized et al. [27] discussed RE policies in Pakistan. They argue that the existing policies and activities have not been sufficient to increase significant changes in the country's renewable sector. Renewable technology equipment must be imported, and this increases the cost of RE projects. Government subsidies reduce the energy costs of crude oil. The complete lack of a marketing and advertising strategy is another weakness of RE policies in Pakistan. Mutual communication and partnerships between different government agencies are also weak. In addition, policies to stabilize and sustain the market must be implemented to ensure investment as well as policies related to profitability and investment in the region [28]. Onifade also conducted a study on hybrid RE support policy in the United Kingdom and concluded that current policies are outdated and ineffective, and policies such as feed-in tariffs and quota obligations need to be used. It is also necessary to develop a market for renewables [37].

In India, the study of RE policies, especially in the field of bioenergy, showed that these policies need to be reviewed and revised. In addition, a detailed analysis of current policies and future plans shows that India has a long way to go to provide energy security for its people. Ravindranath and Balachandra [14] emphasize the urgent need to focus on policymaking and investment. In Pakistan, the analysis of energy policies showed that the current and past governments in the country have designed different energy policies to meet energy demands, but these policies are not sufficient and are not able to fill the supply and demand gap [7].

While all these studies are undoubtedly beneficial, a clear knowledge gap emerges. What is missing from the current research literature is an examination of what RE policies are there and how they work. In fact, the nature of RE policies has not been studied, and little attention has been paid to this area. Most studies have focused on the effectiveness of policies [5-7], and some have examined one or more policies' dimensions and effectiveness [8-12]. Accordingly, the purpose of this study is to provide an overview of RE policies and to fill the gaps in previous studies. The existing policies should be reviewed before they can be revised. In this article, we are using the content analysis method to analyze documents and data. In this way, after collecting the relevant documents, we extract the appropriate topics and keywords in consultation with the research team. Next, codes and categories will be extracted using MAXQDA 18 software, and the results will be reviewed manually. Finally, we analyze the findings and identify the weaknesses and shortcomings of RE policies and refer to the findings of other researchers. It should be noted that a team of five researchers worked together to catalog the words and determine the keywords in the content analysis of the documents. Then, to ensure the high accuracy of the work, the 
results were presented to a number of energy policymaking experts. This step was repeated several times and after final corrections, all defects were fixed as a pre-analysis step.

Overall, this study is an attempt to assess all the dimensions of RE policies. To summarize, several models and modeling methodologies related to the domains of modeling RE policy evaluation were surveyed and reviewed. The present literature lacks a systematic overview of policy assessment modeling techniques to determine their suitability for RE. In order to address this knowledge gap, the aim of this study was to investigate RE policies in Iran's five-year NDP and other upstream national documents. We are solely focused on renewable energies because their integration into the energy system is frequently accompanied by market failures, among other things. Their market penetration, on the other hand, can be seen globally and is unavoidable.

This study provides a framework to assist planners, researchers, and policymakers in adopting a modeling approach based on their questions about the pros and cons of different procedures. A diversity of modeling approaches is highly recommended since this article does not deal with the selection of an approach over another. This study, therefore, systematically summarizes recent approaches and shows which policy planning is suitable for which application scope. It should be noted that there are no restriction-free modeling approaches. In this paper, we will try to answer the following question: "What are Iran's five-year RE policy development plans?" As different policy outcomes influence each other, estimating possible outcomes of future policies using modeling and simulation techniques is highly recommended. We combined a detailed literary review with a systematic review to evaluate the features of various strategies. It is revealed that no best approach is available, but that the benefits and drawbacks in policy assessment modeling are present in each approach. On the other hand, hybrid methods are among the most stable approaches. A compound of dynamic systems and factor-based modeling is an assuring procedure.

\section{Materials and Methods}

In this study, policy prescriptions were developed based on the weaknesses and shortcomings of policy reviews and analyses. In presenting these policies, the experiences of other countries were also considered. For example, the results of previous studies have shown that among organizations and institutions, there is overlap and interference in policy formulation and implementation. Therefore, policies must be adopted to manage the relations between the institutions and put an end to this interference. In this study, we examined the RE policies infrastructure and underlined the shortcomings of these policies. Therefore, we did not change the path, but we paved the way to achieve the goals. It should also be noted that in order to begin the analysis, make appropriate suggestions, and obtain accurate information, many interviews were conducted with experts in this field, which were a guide for researchers in writing this article and analyzing it.

This study is an applied and qualitative one. We identified and analyzed 29 upstream documents related to renewable energies by providing a systematic review of the literature. Then, a qualitative content analysis has been used for the analysis of documents. Content analysis is a method that enables one to include a large amount of textual information and systematically identify its properties. The following categories and sub-categories were created to identify and classify the contents of the documents: (1) Platforms, (2) News, (3) Variation in the number of articles over time, (4) Image of the articles' content, (5) The percentage of articles on information importation, and $(6)$ Themes $[14,15]$. The main themes come out of the documents after classifying and coding categories and sub-categories. This content can be obtained from a variety of sources: books, manuscripts, maps, photographs, interviews, films, e-mails, etc. The content is broken down into conceptual pieces that are then coded or named. Using qualitative analysis, themes are developed. The results are used to infer the messages in the text. Quantitative analysis is planned with a hypothesis and predetermined programming that is designed to test this hypothesis [43]. To achieve the main goal of the study, it was necessary to review and analyze all the approved programs and upstream national documents related to electricity policies in Iran. According to 
the SATBA (statistical report of Iran's renewable energies) [15], these documents were divided into two categories: documents that are directly related to RE production and documents that are indirectly related to RE. In the current study, collecting information has been performed based on these two criteria. Experts in this field were consulted and interviewed because these documents were diverse and needed to be accurately identified in order to enter all relevant documents for analysis, which assisted in ensuring that no documents were overlooked. Furthermore, the validity of the documents was ensured by carefully analyzing all the documents. Therefore, the first part consisted of collecting information on the theoretical foundations of the subject and research records, which was achieved by studying library resources and searching Internet resources. The second part included collecting the required information from the experts of the Ministry of Energy, university professors, and energy policymakers in the study area. Table S1 shows the upstream documents related to RE policies in Iran. In some content analysis studies, a sample should be selected because the researcher is faced with a large volume of content, and it will not be possible to list and analyze all those ideas and information. Therefore, in this study, the samples were selected from content sources. To ensure the reliability of the themes, a checklist of themes was provided to the appropriate experts and authorities and was then adjusted according to their evaluations and opinions. MAXQDA 18 software was used for document analysis and was manually rechecked.

\section{Results and Discussion}

Via the initial coding of the documents, 347 codes were obtained and, in the next step, 11 themes were extracted (Table 1). The details of the extracted themes are given separately in Tables 2-12.

Table 1. RE policies in Iran extracted from upstream documents.

\begin{tabular}{ccc}
\hline Rank & Themes & Total Extracted Code in Themes \\
\hline 1 & Construction of power plants and the development of renewables & 100 \\
2 & Vision and policymaking & 68 \\
3 & Laws and regulations & 30 \\
4 & Institutions and organizations & 25 \\
5 & Agriculture, water, natural resources & 22 \\
6 & Knowledge and applied research & 22 \\
7 & Energy efficiency & 20 \\
8 & Market and energy economy & 16 \\
9 & Education, extension, and development of human resources & 24 \\
11 & Localization of renewable technology and equipment & 10 \\
& International cooperation & 10 \\
\end{tabular}

We attempted to merge two codes at first but, after consulting energy policy experts, we determined that the keywords of the two codes are slightly different. The first part of the sentence refers to "use", which means that this can happen anywhere in the country and can increase the use of RE. The keyword in the second part, on the other hand, is "share". It is worthwhile to investigate the increased use of RE in energy production, but this does not imply that it can be exploited further through energy exports. As a result, we examined these two codes separately. The theme of "construction of power plants and the development of renewables" contains the greatest number of policies in the field of renewables (Table 2). About 100 policies fall into this theme. The most repetition was related to the policy of "constructing power plants for RE production" with nine repetitions and "increasing the share of RE" with eight repetitions. "Increasing the use of RE" seems to be a sensible policy, but considering the fossil fuels cheapness in Iran, in the current situation, an effective plan is required to convince people to move towards replacing these types of fuels. Currently, subsidy discrimination between RE and fossil fuels is about $90 \%$, and this is a huge obstacle to the expansion of the use of renewables instead of fossil fuels. 
"Endeavoring to increase RE considering the priority of hydropower" is a policy that does not conform to the current situation in the country. Problems such as declining rainfall, prolonged droughts, and lowering groundwater levels are preventing this policy from being implemented. Onifade [37] also stated in his results that new renewable policies should be adopted and implemented.

Table 2. RE policies in Iran extracted from upstream documents.

\begin{tabular}{|c|c|c|c|}
\hline Themes & Phrase & Frequency & Total Extracted Code in Themes \\
\hline \multirow{25}{*}{$\begin{array}{l}\text { Construction of power plants } \\
\text { and the development } \\
\text { of renewables }\end{array}$} & Equipping buildings with solar water heaters & 1 & \multirow{25}{*}{100} \\
\hline & $\begin{array}{l}\text { Utilizing the existing potentials } \\
\text { of renewables }\end{array}$ & 1 & \\
\hline & $\begin{array}{l}\text { Empowering and developing infrastructure } \\
\text { related to biomass }\end{array}$ & 1 & \\
\hline & $\begin{array}{c}\text { Promoting the security of reliable and } \\
\text { sustainable energy supply and } \\
\text { appropriate quality }\end{array}$ & 1 & \\
\hline & $\begin{array}{l}\text { Preparing suitable situations for the transfer } \\
\text { and development of renewable technologies }\end{array}$ & 1 & \\
\hline & Constructing power plants for RE production & 9 & \\
\hline & Increasing the share of RE & 8 & \\
\hline & Diversifying the country's energy resources & 5 & \\
\hline & Constructing geothermal power plants & 4 & \\
\hline & Diversifying the country's energy basket & 4 & \\
\hline & Constructing fuel cell power plants & 3 & \\
\hline & Constructing solar power plants & 3 & \\
\hline & Increasing the application of the renewables & 3 & \\
\hline & Developing the use of RE & 3 & \\
\hline & $\begin{array}{l}\text { Promoting the electricity generation ability } \\
\text { from RE }\end{array}$ & 2 & \\
\hline & Diversifying power plant fuels & 2 & \\
\hline & $\begin{array}{l}\text { Development of technology markets related } \\
\text { to energy efficiency and new energies }\end{array}$ & 1 & \\
\hline & $\begin{array}{c}\text { Application development of new technology } \\
\text { types of energy conversion in the } \\
\text { consumption sector }\end{array}$ & 1 & \\
\hline & $\begin{array}{l}\text { Development of greenhouse gas reduction } \\
\text { technologies in the energy sector }\end{array}$ & 1 & \\
\hline & Development of RE conversion technologies & 2 & \\
\hline & $\begin{array}{l}\text { Using new technologies and } \\
\text { technology transfer }\end{array}$ & 1 & \\
\hline & Extending new technologies & 1 & \\
\hline & Using clean technology & 1 & \\
\hline & $\begin{array}{l}\text { Development of electricity and energy } \\
\text { storage technologies and } \\
\text { scattered production }\end{array}$ & 1 & \\
\hline & $\begin{array}{l}\text { Need-oriented development of } \\
\text { engineering technologies }\end{array}$ & 1 & \\
\hline
\end{tabular}


Table 2. Cont.

\begin{tabular}{|c|c|c|c|}
\hline Themes & Phrase & Frequency & Total Extracted Code in Themes \\
\hline & Diversifying power generation technologies & 1 & \\
\hline & $\begin{array}{l}\text { Developing active growth centers in } \\
\text { RE technology }\end{array}$ & 1 & \\
\hline & $\begin{array}{l}\text { Encouraging industries to produce and } \\
\text { develop renewable technology }\end{array}$ & 1 & \\
\hline & $\begin{array}{c}\text { Constructing and upgrading laboratory } \\
\text { network and standard approval } \\
\text { of equipment }\end{array}$ & 1 & \\
\hline & Developing geothermal heat pumps & 1 & \\
\hline & $\begin{array}{l}\text { Manufacturing needed equipment to exploit } \\
\text { geothermal energy resources }\end{array}$ & 1 & \\
\hline & $\begin{array}{l}\text { Dveloping reference laboratories to } \\
\text { qualitatively approve the relevant standards }\end{array}$ & 1 & \\
\hline & $\begin{array}{l}\text { Preparing infrastructure in the exploration } \\
\text { field of geothermal energy resources }\end{array}$ & 1 & \\
\hline & $\begin{array}{l}\text { Purchasing electricity from other power } \\
\text { plants in order to encourage } \\
\text { electricity generation }\end{array}$ & 1 & \\
\hline & Rewarding the builders of new power plants & 1 & \\
\hline & $\begin{array}{l}\text { Facilitating the liquid fuel delivery to } \\
\text { investors in the power plants development }\end{array}$ & 1 & \\
\hline & $\begin{array}{l}\text { Allocating facilities of science parks to } \\
\text { RE activists }\end{array}$ & 1 & \\
\hline & $\begin{array}{l}\text { Promoting the non-governmental sector } \\
\text { participation in the development of RE }\end{array}$ & 1 & \\
\hline & $\begin{array}{l}\text { Encouraging the non-governmental sector to } \\
\text { build renewable power plants }\end{array}$ & 1 & \\
\hline & $\begin{array}{l}\text { Promoting people's participation to support } \\
\text { renewable electricity generation }\end{array}$ & 1 & \\
\hline & $\begin{array}{l}\text { Promoting private sector investment in } \\
\text { renewable electricity generation }\end{array}$ & 1 & \\
\hline & $\begin{array}{l}\text { Supporting large industries in investing in } \\
\text { the construction of renewable systems }\end{array}$ & 1 & \\
\hline & $\begin{array}{l}\text { Transforming waste into energy with the } \\
\text { participation of the private sector }\end{array}$ & 1 & \\
\hline & $\begin{array}{l}\text { Facilitating the development of } \\
\text { knowledge-based economics of RE }\end{array}$ & 1 & \\
\hline & $\begin{array}{l}\text { Endeavoring to increase RE considering the } \\
\text { priority of hydropower }\end{array}$ & 1 & \\
\hline & $\begin{array}{l}\text { Developing new energy application up to } \\
75 \% \text { of people }\end{array}$ & 1 & \\
\hline & $\begin{array}{l}\text { Reducing the share of crude oil in the energy } \\
\text { consumption basket }\end{array}$ & 1 & \\
\hline & $\begin{array}{l}\text { Expanding the use of municipal waste to } \\
\text { produce non-governmental } \\
\text { renewable electricity }\end{array}$ & 1 & \\
\hline
\end{tabular}


Table 2. Cont.

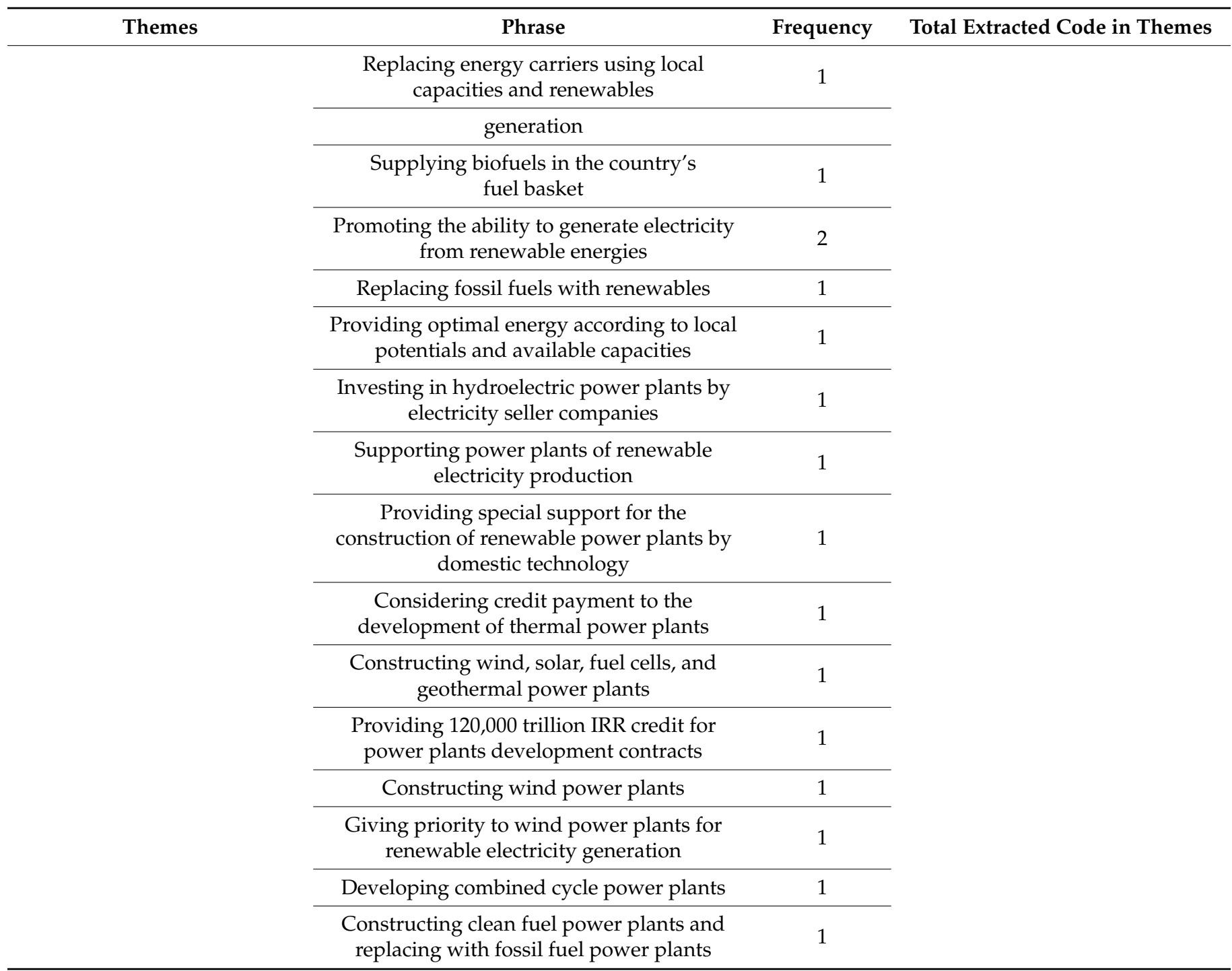

In the theme of "vision and policymaking", the most emphasis is on the renewable electricity guaranteed purchase, which has been repeated 10 times in various documents (Table 3). However, about other types of RE, such as heat or biofuels, there is no guarantee to purchase renewable electricity by the government. This could be a detrimental gap because the production and use of biofuels are on the rise around the world, and governments are paying special attention to these types of energies. In addition, the focus of incentive tariffs is on renewable electricity. It is necessary to make a difference for each type of wind, biomass, and geothermal energy to avoid the policy of non-development and prevent the transfer of huge profits from the governmental sector to the private sector. These findings suggest that this policy should be revised. This type of policy is being adopted and implemented in many countries, with success in some, such as Germany. Even at the household level, the government in Germany provides guaranteed purchase policies [47]. However, in some countries, such as Kenya, the guaranteed purchase policy has not been implemented successfully [48]. For the geothermal, there are different types, such as conventional geothermal energy, hot dry rock, etc. According to Cui et al. [49], the geothermal power generation cost ranges from $0.086 \mathrm{IRR} / \mathrm{kWh}$ to $0.095 \mathrm{IRR} / \mathrm{kWh}$, which is a little higher than the conventional power generation cost. Double-flash or flash-organic Rankine cycle is suggested to be installed for geothermal power generation if more electricity is needed. In addition, in another study by Cui et al. [50], they showed that coupled 
migration and retention of suspended injection particles and reservoir particles can severely damage the formation, especially for weakly consolidated sandstone geothermal reservoirs. Massive detachment of reservoir particles, formation of wormhole-like preferential flow paths, and retention of the injected suspended particles are identified as three successive stages during geothermal energy exploitation via water recycling. The mobile reservoir particles play a leading role in the first two stages, while the injected suspended particles mainly affect the last stage. The high injection-production pressure difference and low concentration of injected suspended particles are conducive to form preferential flow paths, but a severe local reservoir blockage may occur under high mobile reservoir particles [49]. By separating tariffs, the private sector's revenue will be reasonable, and there will be incentives to attract private labor. Onifade [37], in the results of his study, also emphasized that there is a need to use policies such as incentive tariffs and strengthen these policies. Bulut and Muratoglu [45] came to the same conclusion in their findings. In the case of the policy of "gradual elimination of petroleum products subsidies", it is necessary to determine its time and amount. Subsidizing fossil fuels and lack of economic support for renewables will prevent the private sector from active participation. "Policymaking centralization in the unified organization" is one of the policies that has been rightly mentioned, but in practice, this is not the case, and several institutions and organizations are involved in policymaking. "Targeted energy subsidies" was repeated twice. "Encouraging the private sector to participate" was repeated four times, and the goal of providing up to $55 \%$ of the investment in RE by the private sector was mentioned too. However, the way of financing, as well as the type of support, and the required financial resources have not been specified. The proposal of a guaranteed purchase rate of renewable electricity is implemented by the Management and Planning Organization, but its approval is at the discretion of the Economic Council. This contradicts the policy of "policymaking centralization in the unified organization".

Table 3. RE policies in Iran extracted from upstream documents.

\begin{tabular}{|c|c|c|c|}
\hline Themes & Phrase & Frequency & Total Extracted Code in Themes \\
\hline \multirow{11}{*}{ Vision and policymaking } & Guaranteed purchase of renewable electricity & 10 & \multirow{11}{*}{68} \\
\hline & Encouraging the private sector to participate & 4 & \\
\hline & $\begin{array}{l}\text { Suggesting a guaranteed price by the } \\
\text { Country's Management and } \\
\text { Planning Organization }\end{array}$ & 2 & \\
\hline & Targeted energy subsidies & 2 & \\
\hline & $\begin{array}{l}\text { Supporting the establishment and } \\
\text { strengthening of technical infrastructure for } \\
\text { the development of renewables }\end{array}$ & 1 & \\
\hline & $\begin{array}{c}\text { Evaluation of technological capabilities of } \\
\text { domestic companies in the field } \\
\text { of renewables }\end{array}$ & 1 & \\
\hline & $\begin{array}{l}\text { Strategic studies to identify } \\
\text { prioritized technologies }\end{array}$ & 1 & \\
\hline & $\begin{array}{l}\text { Supporting the development of renewable } \\
\text { equipment market }\end{array}$ & 1 & \\
\hline & $\begin{array}{l}\text { Facilitating the development of } \\
\text { RE technologies }\end{array}$ & 1 & \\
\hline & $\begin{array}{l}\text { Designing the macro plans to achieve design } \\
\text { knowledge of prioritized technologies }\end{array}$ & 1 & \\
\hline & $\begin{array}{l}\text { Allocation of funds for the development of } \\
\text { renewable technologies }\end{array}$ & 1 & \\
\hline
\end{tabular}


Table 3. Cont.

Developing standards and software related

$$
\text { to geothermal energy }
$$

\begin{tabular}{cc}
\hline Supporting energy sector innovations & 1 \\
\hline $\begin{array}{c}\text { Production of } 12,000 \mathrm{MW} \text { of electricity in the } \\
\text { form of combined cycle }\end{array}$ & 1 \\
\hline
\end{tabular}

Achieving the region's first position in the field of science and technology in solar energy

Placing among the top 5 countries in the world in scientific and technological products

Acquiring the first place in the region in the
field of RE science and technology

A comprehensive program to reduce energy
production and consumption pollution
Reducing greenhouse gas emissions, at least
10 million tons by 1404

\begin{tabular}{cl}
\hline $\begin{array}{c}\text { Purchasing renewable equipment from } \\
\text { manufacturers and using it by } \\
\text { government agencies }\end{array}$ & 1 \\
\hline $\begin{array}{c}\text { Sale of electricity inside after the guaranteed } \\
\text { purchase period and the Ministry of } \\
\text { Power's approval }\end{array}$ & 1 \\
\hline $\begin{array}{c}\text { The policy of reducing guaranteed purchase } \\
\text { tariffs of renewable electricity }\end{array}$ & 1 \\
\hline $\begin{array}{c}\text { Incentive policies for the development of } \\
\text { small-scale private power plants }\end{array}$ & 1 \\
\hline Determining the guaranteed purchase price & 1 \\
\hline $\begin{array}{c}\text { The gradual elimination of petroleum } \\
\text { products subsidies }\end{array}$ & 1 \\
\hline $\begin{array}{c}\text { Review of tariffs and customs duties on } \\
\text { renewable imported equipment }\end{array}$ & 1 \\
\hline Actualizing consumption electricity tariffs & 1 \\
\hline Guaranteed purchase of power plants & 1 \\
\hline Allocation of funds for the development \\
of renewables
\end{tabular}


Table 3. Cont.

Enactment of the guaranteed purchase price of renewable electricity by the Economic Council

\begin{tabular}{|c|c|}
\hline $\begin{array}{l}\text { Giving a mission to the Ministries of Oil and } \\
\text { Power in preparing a comprehensive energy } \\
\text { plan for the country }\end{array}$ & 1 \\
\hline Putting the non-governmental sector first & 1 \\
\hline $\begin{array}{l}\text { Private sector participation of up to } 55 \% \text { in } \\
\text { investments in renewables }\end{array}$ & 1 \\
\hline $\begin{array}{l}\text { Encouragement of private investors to } \\
\text { participate in RE industries }\end{array}$ & 1 \\
\hline $\begin{array}{l}\text { Determining the share of the private and } \\
\text { cooperative sector in electricity production } \\
\text { up to } 10,000 \mathrm{MW}\end{array}$ & 1 \\
\hline Developing a document for RE development & 1 \\
\hline $\begin{array}{l}\text { Adopting the internal and external } \\
\text { approaches to the development of RE }\end{array}$ & 1 \\
\hline $\begin{array}{l}\text { Providing sustainable financial resources to } \\
\text { expand the use of RE }\end{array}$ & 1 \\
\hline Producing $5000 \mathrm{MW}$ wind and solar energy & 1 \\
\hline $\begin{array}{l}\text { Producing } 3 \% \text { of the country's primary } \\
\text { energy supply until } 1404 \text { from renewables }\end{array}$ & 1 \\
\hline $\begin{array}{l}\text { Spatial planning for the sustainable } \\
\text { development of RE }\end{array}$ & 1 \\
\hline $\begin{array}{l}\text { Developing a document to set quantitative } \\
\text { goals for each of the renewable resources }\end{array}$ & 1 \\
\hline $\begin{array}{l}\text { Policymaking centralization in the } \\
\text { unified organization }\end{array}$ & 1 \\
\hline $\begin{array}{l}\text { Preserving the role of government } \\
\text { policymaking and monitoring }\end{array}$ & 1 \\
\hline $\begin{array}{l}\text { Centralization on policymaking and } \\
\text { planning and decentralization } \\
\text { on implementation }\end{array}$ & 1 \\
\hline $\begin{array}{l}\text { Role differentiation of policymakers, } \\
\text { executives, and supervisors }\end{array}$ & 1 \\
\hline $\begin{array}{l}\text { Improving the policymaking process in order } \\
\text { to achieve rapid growth in priority areas }\end{array}$ & 1 \\
\hline $\begin{array}{l}\text { Involvement of stakeholders in the } \\
\text { renewables policymaking by the Ministry } \\
\text { of Power }\end{array}$ & 1 \\
\hline
\end{tabular}

In the theme of "laws and regulations", discriminations in the renewables development laws were observed (Table 4). For example, the preparation of the atlas for renewable resources has been repeated twice in general, but the case of geothermal energy has been considered separately. The issue of financing the projects of transforming waste into energy has been mentioned separately, while Iran has a very high potential for solar and wind energy [16,35]. The development and implementation of waste disposal and recycling guidelines for each sector of production should be defined separately, while it is generally mentioned in the policies. This seems very important and necessary in the agricultural 
sector because the agricultural sector of Iran leaves a significant amount of waste every year [51]. This matter can be a huge potential for biofuel production. However, little attention has been paid to biofuels in the theme of laws and regulations. The special rules of renewables that have an emphasis on the agricultural sector are weak. Of course, apart from geothermal energy, other energy types have not been mentioned separately.

Table 4. RE policies in Iran extracted from upstream documents.

\begin{tabular}{|c|c|c|c|}
\hline Themes & Phrase & Frequency & Total Extracted Code in Themes \\
\hline \multirow{20}{*}{ Laws and regulations } & $\begin{array}{c}\text { Measurement of capacity and preparation of } \\
\text { the country's complete atlas for } \\
\text { renewable resources }\end{array}$ & 2 & \multirow{20}{*}{30} \\
\hline & $\begin{array}{l}\text { Receiving imposition from subscribers } \\
\text { outside the defined consumption pattern }\end{array}$ & 1 & \\
\hline & $\begin{array}{l}\text { Requisiteness for using renewables instead of } \\
\text { fossil fuel in all urban factories }\end{array}$ & 1 & \\
\hline & $\begin{array}{l}\text { Provision of atlas and geothermal energy } \\
\text { database in the country }\end{array}$ & 1 & \\
\hline & $\begin{array}{l}\text { Developing a national standard system and } \\
\text { required quality approval }\end{array}$ & 1 & \\
\hline & $\begin{array}{l}\text { Impelling industries to reduce } \\
\text { environmental pollution }\end{array}$ & 1 & \\
\hline & Funding to transform waste into energy & 1 & \\
\hline & $\begin{array}{l}\text { Forcing the national grid to buy renewable } \\
\text { electricity produced }\end{array}$ & 1 & \\
\hline & $\begin{array}{l}\text { Paying an equivalent amount of fuel subsidy } \\
\text { to rural RE companies }\end{array}$ & 1 & \\
\hline & $\begin{array}{l}\text { Payment of electricity purchase subsidy to } \\
\text { small scale producers }\end{array}$ & 1 & \\
\hline & $\begin{array}{l}\text { The Ministry of Power is obliged to purchase } \\
\text { electricity from the private and public sectors }\end{array}$ & 1 & \\
\hline & $\begin{array}{l}\text { Financial support for producers of renewable } \\
\text { materials and equipment }\end{array}$ & 1 & \\
\hline & $\begin{array}{l}\text { Providing graduates with special facilities to } \\
\text { establish knowledge-based companies }\end{array}$ & 1 & \\
\hline & $\begin{array}{l}\text { Considering environmental taxes (carbon } \\
\text { tax) on petroleum products consumption }\end{array}$ & 1 & \\
\hline & $\begin{array}{c}\text { Providing permission to the Ministry of } \\
\text { Power to purchase renewable sources } \\
\text { of electricity }\end{array}$ & 1 & \\
\hline & $\begin{array}{l}\text { Encouraging industries to use } \\
\text { renewable technologies }\end{array}$ & 1 & \\
\hline & $\begin{array}{l}\text { Allocation of part of government subsidies to } \\
\text { renewable electricity development }\end{array}$ & 1 & \\
\hline & $\begin{array}{l}\text { Developing an optimal model of economic } \\
\text { substitution between energy carriers }\end{array}$ & 1 & \\
\hline & $\begin{array}{l}\text { Supporting industries to use } \\
\text { geothermal energy }\end{array}$ & 1 & \\
\hline & $\begin{array}{l}\text { Granting export licenses to renewable } \\
\text { electricity producers }\end{array}$ & 1 & \\
\hline
\end{tabular}


Table 4. Cont.

\begin{tabular}{|c|c|c|c|}
\hline Themes & Phrase & Frequency & Total Extracted Code in Themes \\
\hline & $\begin{array}{l}\text { Preparing the country's comprehensive } \\
\text { energy plan according to the country's } \\
\text { national energy document }\end{array}$ & 1 & \\
\hline & $\begin{array}{l}\text { Determining criteria, indicators, and } \\
\text { standards related to RE production }\end{array}$ & 1 & \\
\hline & $\begin{array}{l}\text { Developing and implementing waste } \\
\text { disposal and recycling instructions for } \\
\text { production sectors }\end{array}$ & 1 & \\
\hline & $\begin{array}{l}\text { Providing legal infrastructure to } \\
\text { develop renewables }\end{array}$ & 1 & \\
\hline & $\begin{array}{c}\text { Coordination between different sectors of the } \\
\text { implementer of the laws related } \\
\text { to renewables }\end{array}$ & 1 & \\
\hline & $\begin{array}{l}\text { Developing rules to support energy } \\
\text { sector innovations }\end{array}$ & 1 & \\
\hline & $\begin{array}{l}\text { Regulating the rules for developing the use } \\
\text { of renewable electricity }\end{array}$ & 1 & \\
\hline & $\begin{array}{l}\text { Simplifying the laws and regulations related } \\
\text { to renewables }\end{array}$ & 1 & \\
\hline & $\begin{array}{l}\text { Updating the rules and regulations in the } \\
\text { field of renewables }\end{array}$ & 1 & \\
\hline
\end{tabular}

In the theme of "institutions and organizations", the emphasis is on supporting the private sector in RE production (Table 5). The results of Schmid et al. [3] also showed that private sector participation played a key role in developing the installed capacity of renewable electricity. However, there are many contradictions in this theme. For example, in the adopted policies, the task of identifying the required technology in the field of energy has been assigned to the Ministries of Oil, Industry and Mining, Agriculture, and Power, but elsewhere it has been emphasized and repeated that all the duties of the Ministry of Agriculture, Atomic Energy Organization, and other institutions in the field of RE should be transferred to the Ministry of Power. It was also noted that the Ministry of Petroleum should support the use of RE in solar water heaters, photovoltaic systems, wind turbines, wind pumps, and gas extraction from biomass resources (gasification). Here, the level and amount of support is not defined, and it is inconsistent with entrusting all the renewable affairs to the Ministry of Power. In this theme, cooperation between institutions and organizations is emphasized.

Table 5. RE policies in Iran extracted from upstream documents.

\begin{tabular}{|c|c|c|c|}
\hline Themes & Phrase & Frequency & Total Extracted Code in Themes \\
\hline \multirow{4}{*}{ Institutions and organizations } & $\begin{array}{l}\text { Supporting the private sector in } \\
\text { RE production }\end{array}$ & 2 & \multirow{4}{*}{25} \\
\hline & $\begin{array}{l}\text { Supporting the private and cooperative small } \\
\text { power plants }\end{array}$ & 1 & \\
\hline & $\begin{array}{c}\text { Making cooperation between governmental } \\
\text { and non-governmental organizations } \\
\text { and companies }\end{array}$ & 1 & \\
\hline & $\begin{array}{c}\text { Supporting the use of renewable resources in } \\
\text { solar water heaters by the Ministry } \\
\text { of Petroleum }\end{array}$ & 1 & \\
\hline
\end{tabular}


Table 5. Cont.

Supporting the use of renewable resources in the photovoltaic system by the Ministry of Petroleum

\begin{tabular}{c} 
Supporting the use of renewable resources in \\
wind turbines by the Ministry of Petroleum \\
\hline $\begin{array}{c}\text { Supporting the use of renewable resources in } \\
\text { wind pumps by the Ministry of Petroleum }\end{array}$ \\
\hline $\begin{array}{c}\text { Supporting the gas extraction from biomass } \\
\text { resources by the Ministry of Petroleum }\end{array}$ \\
Establishing organizations to make \\
communication between producers \\
and consumers
\end{tabular}

Participation of the Environment

Organization and ministries in reducing greenhouse gases

\begin{tabular}{|c|c|}
\hline $\begin{array}{l}\text { Emphasis on the role of the Ministry of } \\
\text { Power in transferring new technologies }\end{array}$ & 1 \\
\hline $\begin{array}{c}\text { Establishing an independent organization to } \\
\text { exploit renewable resources }\end{array}$ & 1 \\
\hline $\begin{array}{l}\text { Emphasis on the role of the Ministry of } \\
\text { Power in localizing new technologies }\end{array}$ & 1 \\
\hline $\begin{array}{l}\text { Identifying the required technology in the } \\
\text { field of energy by the Ministry of Power }\end{array}$ & 1 \\
\hline $\begin{array}{l}\text { Cooperating with the Strategic Council at the } \\
\text { Solar Technology Development Center }\end{array}$ & 1 \\
\hline $\begin{array}{l}\text { Institutions cooperation to provide the } \\
\text { necessary mechanism for the use of RE }\end{array}$ & 1 \\
\hline $\begin{array}{c}\text { Transferring the legal duties of other } \\
\text { institutions in the field of renewables to the } \\
\text { Ministry of Power }\end{array}$ & 1 \\
\hline $\begin{array}{l}\text { Identifying the required technology in } \\
\text { energy supply by the Ministry of Oil }\end{array}$ & 1 \\
\hline $\begin{array}{l}\text { Identifying the required technology in the } \\
\text { field of energy by the Ministry of Industry, } \\
\text { Mine, and Trade }\end{array}$ & 1 \\
\hline $\begin{array}{c}\text { Identifying the required technology in the } \\
\text { field of energy by the Ministry of } \\
\text { Agriculture-Jahad }\end{array}$ & 1 \\
\hline $\begin{array}{c}\text { Centralizing all legal activities of RE in the } \\
\text { Ministry of Power }\end{array}$ & 1 \\
\hline $\begin{array}{c}\text { Assigning the duties of Agriculture-Jahad in } \\
\text { the field of renewables to the Ministry } \\
\text { of Power }\end{array}$ & 1 \\
\hline $\begin{array}{c}\text { Assigning the tasks of the Atomic Energy } \\
\text { Organization in the field of renewables to the } \\
\text { Ministry of Power }\end{array}$ & 1 \\
\hline
\end{tabular}


The analysis of the theme of "agriculture, water, natural resources, and the environment" showed that most policies in this sector emphasize the use of agricultural and forestry waste in the biofuels production which, due to the high rate of agricultural waste in Iran, there is a great potential in this sector (Table 6). "Electrifying agricultural wells" is one of the most repeated policies. According to the statistics provided by the Ministry of Power, in the country, there are more than one million water wells, including deep and semi-deep, which have been drilled with legal permits. The number of deep wells dug in the country is over 205,511 rings and the number of semi-deep wells is 553,087 [52]. The amount of electricity consumed by this number of wells is significant. Therefore, the use of renewable resources to generate electricity, in addition to saving electricity consumption, reduces the heavy costs it imposes on the government. Water pumps play an important role in agricultural water management [53]. "Developing the use of new technologies in the agricultural water sector" reminds of the need to use solar and wind pumps. However, special policies for the development of solar and wind energy in the agricultural sector have received less attention, and in addition to adopting policies to expand the use of solar and wind energy in this sector, extension training is needed for farmers and rural people, especially rural women who have an important role in agriculture.

Table 6. RE policies in Iran extracted from upstream documents.

\begin{tabular}{|c|c|c|c|}
\hline Themes & Phrase & Frequency & Total Extracted Code in Themes \\
\hline \multirow{19}{*}{$\begin{array}{l}\text { Agriculture, water, and } \\
\text { natural resources }\end{array}$} & Electrifying agricultural wells & 3 & \multirow{19}{*}{22} \\
\hline & $\begin{array}{l}\text { Reconnaissance of new and eco-friendly } \\
\text { technologies }\end{array}$ & 1 & \\
\hline & $\begin{array}{l}\text { Identifying passive defense patterns and crisis } \\
\text { management in the environment sector }\end{array}$ & 1 & \\
\hline & Waste-to-Energy Information in Cities & 1 & \\
\hline & $\begin{array}{l}\text { Reducing greenhouse gases and preventing } \\
\text { environmental pollution }\end{array}$ & 2 & \\
\hline & Developing biomass resources & 1 & \\
\hline & $\begin{array}{c}\text { Achieving a biogas capacity of gas consumed from } \\
\text { agricultural waste ( } 2 \text { in } 1000)\end{array}$ & 1 & \\
\hline & Electrification of villages using renewable sources & 1 & \\
\hline & $\begin{array}{c}\text { Facilities payment for the electrification of } \\
\text { agricultural wells }\end{array}$ & 1 & \\
\hline & $\begin{array}{c}\text { Producing biogas from agricultural and } \\
\text { livestock waste }\end{array}$ & 1 & \\
\hline & Reforming forestry and agriculture methods & 1 & \\
\hline & $\begin{array}{l}\text { Financing } 4000 \text { billion IRR for the development of } \\
\text { the rural renewable electricity network }\end{array}$ & 1 & \\
\hline & $\begin{array}{l}\text { Spending the electricity bill to develop rural } \\
\text { renewable electricity network }\end{array}$ & 1 & \\
\hline & $\begin{array}{l}\text { Delivering the wells electrification equipment by } \\
\text { renewable resources to farmers }\end{array}$ & 1 & \\
\hline & $\begin{array}{l}\text { Using forest and agricultural waste to produce } \\
\text { renewable non-governmental electricity }\end{array}$ & 1 & \\
\hline & Extending the agricultural waste to produce biogas & 1 & \\
\hline & $\begin{array}{c}\text { Development and use of new technologies in the } \\
\text { agricultural water sector }\end{array}$ & 1 & \\
\hline & $\begin{array}{l}\text { Identifying passive defense patterns and crisis } \\
\text { management in the water and resources sector }\end{array}$ & 1 & \\
\hline & $\begin{array}{l}\text { Development and use of new technologies in the } \\
\text { environment and natural resources }\end{array}$ & 1 & \\
\hline
\end{tabular}


The theme of "knowledge and applied research" emphasizes the acquisition of technology and supporting research related to RE (Table 7). In this theme, the supporting research has been repeated many times, and the connection between industry and universities has been considered necessary. The link between "industry and university" is a supplementary policy for the "development of need-oriented engineering sciences" policy. In addition, wind and solar energy are also priorities in this part of policies, which conform to the potential of renewable resources in Iran. "Promoting the knowledge of access to freshwater such as solar desalination" is a policy that can help provide drinking water resources for the country because Iran has an average rainfall of $250 \mathrm{~mm}$ per year [37] and this is one-third of the global average rainfall $[39,40]$. Droughts in Iran have caused a lot of damage [41] and water scarcity is a serious problem [40]. Due to the large number of sunny days in Iran [42], this solar desalination will meet the water needs of deprived areas.

Table 7. RE policies in Iran extracted from upstream documents.

\begin{tabular}{|c|c|c|c|}
\hline Themes & Phrase & Frequency & Total Extracted Code in Themes \\
\hline \multirow{21}{*}{ Knowledge and applied research } & $\begin{array}{l}\text { Acquisition of technology and technical knowledge of } \\
\text { RE }\end{array}$ & 1 & \multirow{21}{*}{22} \\
\hline & More use of engineering science and technology & 1 & \\
\hline & $\begin{array}{c}\text { Acquisition of technology and technical knowledge of } \\
\text { new energies }\end{array}$ & 1 & \\
\hline & $\begin{array}{l}\text { Giving priority to solar and wind energy research in } \\
\text { electricity generation }\end{array}$ & 1 & \\
\hline & $\begin{array}{l}\text { Development of knowledge and technologies related } \\
\text { to biomass }\end{array}$ & 1 & \\
\hline & $\begin{array}{l}\text { Helping equip industrial research scientific centers and } \\
\text { geothermal laboratories }\end{array}$ & 1 & \\
\hline & $\begin{array}{l}\text { Supporting the establishment of the RE Technology } \\
\text { Engineering and Research Unit }\end{array}$ & 1 & \\
\hline & $\begin{array}{l}\text { Supporting design, construction, and testing of } \\
\text { experimental plans }\end{array}$ & 1 & \\
\hline & $\begin{array}{l}\text { Extraction of science and technology priorities with an } \\
\text { advantage-oriented and need-oriented approach }\end{array}$ & 1 & \\
\hline & $\begin{array}{l}\text { Facilitating applied research of renewable } \\
\text { technology development }\end{array}$ & 1 & \\
\hline & $\begin{array}{l}\text { Supporting research on upgrading equipment and } \\
\text { renewable local systems }\end{array}$ & 1 & \\
\hline & Supporting research on RE & 1 & \\
\hline & Development of RE research & 1 & \\
\hline & Supporting priority research in the field of renewables & 1 & \\
\hline & Supporting applied research in the field of renewables & 1 & \\
\hline & $\begin{array}{l}\text { Research for the connection of science and technology } \\
\text { with the process of energy production and supply }\end{array}$ & 1 & \\
\hline & $\begin{array}{l}\text { Developing and implementing a knowledge } \\
\text { management system }\end{array}$ & 1 & \\
\hline & Development of need-oriented engineering sciences & 1 & \\
\hline & $\begin{array}{l}\text { Promoting knowledge of access to freshwater such as } \\
\text { solar desalination }\end{array}$ & 1 & \\
\hline & $\begin{array}{l}\text { Supporting research and developing new technologies } \\
\text { through funding }\end{array}$ & 1 & \\
\hline & $\begin{array}{l}\text { Supporting the relationship between industry } \\
\text { and academia }\end{array}$ & 1 & \\
\hline
\end{tabular}


The seventh theme is named "energy efficiency" (Table 8). In the theme of energy efficiency, there was a lot of emphasis on "consumption pattern reform", which was repeated eight times, and "increasing the efficiency of power plants", which was repeated four times. It also points to the construction of combined cycle power plants which can be more efficient. Energy losses in Iran are high. Iran, with a population of 80 million people, pays IRR 45 billion in yearly energy subsidies, whilst China, with a population of 1.5 billion people, pays IRR 38 billion. Therefore, energy subsidies in a country such as China, which has a population 18 times that of Iran, are about 7 times lower than in Iran, and that can be very thoughtful for policymakers and planners. According to the statistics from the Parliament Research Center [54], the loss of power plant conversion was $63.1 \%$, amounting to 253 million crude oil barrels. In this report, the Parliament Research Center has emphasized that by converting gas power plants into a combined cycle and increasing the efficiency of power plants, it is easy to prevent energy loss in this sector [54]. This amount of unauthorized losses can be prevented by correcting inefficiencies. "Using new energy in buildings" is very effective in reducing energy consumption and increasing efficiency, but it has not yet achieved much attention in the implementation phase. According to the country's energy balance sheet in 2016, 396 million barrels of crude oil are consumed annually in the domestic sector [55].

Table 8. RE policies in Iran extracted from upstream documents.

\begin{tabular}{|c|c|c|c|}
\hline Themes & Phrase & Frequency & Total Extracted Code in Themes \\
\hline \multirow{10}{*}{ Energy efficiency } & Consumption pattern reform & 8 & \multirow{10}{*}{20} \\
\hline & Increasing the efficiency of power plants & 4 & \\
\hline & $\begin{array}{l}\text { Development of energy consumption } \\
\text { reduction technologies } \\
\text { emphasizing renewables }\end{array}$ & 1 & \\
\hline & $\begin{array}{l}\text { Efficient and optimum use of energy } \\
\text { resources along with demand } \\
\text { management development }\end{array}$ & 1 & \\
\hline & $\begin{array}{c}\text { Management development of electrical } \\
\text { energy demand in order to optimize the use } \\
\text { of energy }\end{array}$ & 1 & \\
\hline & $\begin{array}{l}\text { Increasing the thermal efficiency of } \\
\text { power plants }\end{array}$ & 1 & \\
\hline & Effective use of RE in buildings & 1 & \\
\hline & $\begin{array}{l}\text { Creating an appropriate mechanism for } \\
\text { productivity growth (energy) }\end{array}$ & 1 & \\
\hline & $\begin{array}{l}\text { Increasing the productivity of } \\
\text { electricity generation }\end{array}$ & 1 & \\
\hline & $\begin{array}{l}\text { Allocating governmental subsidies to } \\
\text { increase energy productivity }\end{array}$ & 1 & \\
\hline
\end{tabular}

The "market and energy economy" theme was the eighth theme to be investigated (Table 9) which, of course, has not been properly addressed. The policies of this sector often emphasize the "economic use of clean energy" but do not define the necessary strategies and financial resources. Target markets must be identified and needs assessment is necessary to be conducted. "Achieving a 10\% share of equipment exports of all renewable equipment" is a policy that requires a long way to go and, of course, requires more supportive policies and infrastructure, as it has not yet been successful in meeting domestic needs. 
Table 9. RE policies in Iran extracted from upstream documents.

\begin{tabular}{|c|c|c|c|}
\hline Themes & Phrase & Frequency & Total Extracted Code in Themes \\
\hline \multirow{12}{*}{ Market and energy economy } & Economic use of clean energy & 5 & \multirow{12}{*}{16} \\
\hline & Commercializing the sample projects of RE & 1 & \\
\hline & Commercializing RE technologies & 1 & \\
\hline & $\begin{array}{l}\text { Publishing participation bond of economic } \\
\text { projects by companies of the Ministry } \\
\text { of Power }\end{array}$ & 1 & \\
\hline & $\begin{array}{c}\text { Private sector participation in electricity } \\
\text { guaranteed purchase }\end{array}$ & 1 & \\
\hline & $\begin{array}{l}\text { Creating a sustainable business environment } \\
\text { in the field of renewables }\end{array}$ & 1 & \\
\hline & $\begin{array}{l}\text { Viewing change in oil revenues and } \\
\text { emphasizing the renewable } \\
\text { resources economy }\end{array}$ & 1 & \\
\hline & $\begin{array}{l}\text { Achieving } 10 \% \text { share of equipment exports } \\
\text { of all renewable equipment }\end{array}$ & 1 & \\
\hline & $\begin{array}{l}\text { Increasing the export share of Iranian brand } \\
\text { in the renewables global market }\end{array}$ & 1 & \\
\hline & $\begin{array}{c}\text { Developing a comprehensive energy strategy } \\
\text { emphasizing Iran's share increase in } \\
\text { the market }\end{array}$ & 1 & \\
\hline & $\begin{array}{l}\text { Supporting the formation and development } \\
\text { of RE knowledge-based services market }\end{array}$ & 1 & \\
\hline & $\begin{array}{l}\text { Supporting the formation and development } \\
\text { of the renewable electricity market }\end{array}$ & 1 & \\
\hline
\end{tabular}

The next theme was the "education, extension, and development of human resources" theme, which included 24 codes (Table 10). Education and extension are important factors in the development of production and the use of RE. Education, extension, advertising, and culture-making are the policies that have been mentioned many times. In this section, RE is mentioned in all the policies in general, but geothermal energy is specifically referred to as "education, culture-making, and awareness of geothermal energy". Holding exhibitions and implementing sample projects are the policies that can be effective in introducing RE to society. The policy of establishing RE cooperatives can play a significant role in the development and exploitation of this kind of resource, but despite the emphasis on the upstream documents, the implementation of this policy has still failed to be successful. In addition, the issue of RE cooperatives has not been addressed, but it should be. Germany has been very successful in this regard. Participation in these cooperatives can increase the social acceptance of projects [42], and Iran can also take advantage of these experiences. Such experiences also focused on training, education, and access to skilled manpower. However, most of all, it has insisted on specialized manpower in the field of solar energy. It is clear that it is necessary to strengthen international relations so that human resources can benefit from the experiences and knowledge of developed countries in this field, but the major obstacle in this way is the political and economic conditions in Iran, which is facing international sanctions. In addition, some policies are needed to train specialists in other areas of energy, such as wind, geothermal, and biomass. The human resources dimension has received less attention and, if well strengthened, it could play a significant role in job creation. 
Table 10. RE policies in Iran extracted from upstream documents.

\begin{tabular}{|c|c|c|c|}
\hline Themes & Phrase & Frequency & Total Extracted Code in Themes \\
\hline \multirow{22}{*}{$\begin{array}{l}\text { Education, extension, and } \\
\text { development of } \\
\text { human resources }\end{array}$} & Developing skilled manpower & 2 & \multirow{22}{*}{24} \\
\hline & $\begin{array}{l}\text { Leading the education system to provide and } \\
\text { attract the needed elite and } \\
\text { specialized personnel }\end{array}$ & 1 & \\
\hline & $\begin{array}{c}\text { Making network between domestic and } \\
\text { foreign specialized to take advantage } \\
\text { of opportunities }\end{array}$ & 1 & \\
\hline & $\begin{array}{l}\text { Accomplishing expertise courses for solar } \\
\text { electricity systems specialists }\end{array}$ & 1 & \\
\hline & Attention to human capital & 1 & \\
\hline & $\begin{array}{l}\text { Dispatching specialists abroad to learn the } \\
\text { required skills and technology }\end{array}$ & 1 & \\
\hline & $\begin{array}{l}\text { Establishing a database and experts network } \\
\text { in the field of solar energy }\end{array}$ & 1 & \\
\hline & $\begin{array}{l}\text { Achieving capable and specialized } \\
\text { manpower in the field of solar energy }\end{array}$ & 1 & \\
\hline & $\begin{array}{l}\text { Forcing SANA to raise public awareness } \\
\text { about renewables }\end{array}$ & 1 & \\
\hline & $\begin{array}{l}\text { Encouraging graduates to set up private and } \\
\text { cooperative knowledge-based companies }\end{array}$ & 1 & \\
\hline & $\begin{array}{l}\text { Education and culture-making about } \\
\text { geothermal energy }\end{array}$ & 1 & \\
\hline & $\begin{array}{l}\text { Subsidies for the extension of RE } \\
\text { in industries }\end{array}$ & 1 & \\
\hline & Creating sample projects in the field of RE & 1 & \\
\hline & General and specialized culturalization in RE & 2 & \\
\hline & $\begin{array}{l}\text { Creating academic specialized, technical, and } \\
\text { professional disciplines and sub-disciplines } \\
\text { in the field of renewables }\end{array}$ & 1 & \\
\hline & $\begin{array}{l}\text { Creating RE production systems to } \\
\text { encourage the private sector }\end{array}$ & 1 & \\
\hline & Culturalization in the use of RE & 1 & \\
\hline & Implementation of sample RE projects & 1 & \\
\hline & $\begin{array}{l}\text { Designing titles related to renewable } \\
\text { technology in university courses }\end{array}$ & 1 & \\
\hline & $\begin{array}{l}\text { Public and specialized information giving } \\
\text { and extension on RE }\end{array}$ & 1 & \\
\hline & $\begin{array}{l}\text { Holding an exhibition of RE } \\
\text { industry achievements }\end{array}$ & 1 & \\
\hline & $\begin{array}{l}\text { Education, extension, advertisement, and } \\
\text { culturalization for all audiences }\end{array}$ & 1 & \\
\hline
\end{tabular}

The theme of "localization of renewable technology and equipment" includes 10 codes (Table 11) that emphasize the use of localized technologies, but in this theme, all the technologies were mentioned in general, and only the solar energy and the photovoltaic system are emphasized separately. Considering the slow development procedure of renewable technologies in current days, "achieving the first rank in local industrial production of solar thermal technology and photovoltaics", "presence among the top 5 Asian countries in 
competitive domestic industrial products", and the "localization of renewable equipment up to $80 \%$ of installed equipment up to 1404 " seem too dreamy.

Table 11. RE policies in Iran extracted from upstream documents.

\begin{tabular}{|c|c|c|c|}
\hline Themes & Phrase & Frequency & Total Extracted Code in Themes \\
\hline \multirow{8}{*}{$\begin{array}{l}\text { Localization of renewable } \\
\text { technology and equipment }\end{array}$} & $\begin{array}{l}\text { Allocation of funds for renewable } \\
\text { technologies localization }\end{array}$ & 2 & \multirow{8}{*}{10} \\
\hline & $\begin{array}{l}\text { Localization and commercialization of solar } \\
\text { energy technology and equipment }\end{array}$ & 1 & \\
\hline & $\begin{array}{l}\text { Transferring and localizing } \\
\text { environmental technologies }\end{array}$ & 1 & \\
\hline & $\begin{array}{c}\text { Emphasis on localized and commercialized } \\
\text { RE technologies }\end{array}$ & 2 & \\
\hline & $\begin{array}{l}\text { Occurring among the top } 5 \text { Asian countries } \\
\text { in competitive domestic industrial }\end{array}$ & 1 & \\
\hline & $\begin{array}{l}\text { Achieving the first rank in local industrial } \\
\text { production of solar thermal technology } \\
\text { and photovoltaics }\end{array}$ & 1 & \\
\hline & $\begin{array}{l}\text { Establishing an international company in the } \\
\text { field of manufacturing and localizing } \\
\text { thermal systems }\end{array}$ & 1 & \\
\hline & $\begin{array}{l}\text { Localization of renewable equipment up to } \\
80 \% \text { of installed equipment up to } 1404\end{array}$ & 1 & \\
\hline
\end{tabular}

The last theme was the "international cooperation" theme which included 10 codes (Table 12) related to RE development. Iran's membership in the International RE Agency and Iran's adhesion to the Kyoto Protocol were among Iran's most important legal actions. Cooperation with international institutions and companies is an effective step in advancing the exploitation of renewable resources, but in the current situation and given the sanctions imposed on Iran by the global society, there are widespread obstacles in this way. At a glance, it can be said that the policies in this area are weak and need to be strengthened. Chen, in his study, stated that international cooperation between countries is effective in developing renewables [56]. Chang et al. [28] also concluded that cooperation between countries could help develop renewable markets.

Due to its various environmental and climatic conditions, Iran can supply energy from various renewable sources. Because of the abundance of fossil fuels and due to the high investments of the past, strategies and proper measures related to RE resources have often been ignored [22]. Moreover, until the late 1990s, there was no special plan for RE resources in Iran's policy records $[13,22]$. Because of the low cost of energy from fossil resources in Iran, government employees, artisans, and customers are less interested in using RE resources [26]. The first general policy document of Iran, published in 2000, is related to RE resources [57]. Because of environmental concerns, the document emphasizes the variety of energy resources in Iran, efforts to increase the share of RE with hydropower priority, and efforts to obtain technology and scientific information of new energy and power plants such as wind and solar, fuel, and geothermal energy [57]. The 6th 5-year Economic Development Plan Act in 2017-2021 was the first document that emphasized the performance of a particular goal for RE [19]. By the end of the program, the government should enhance the share of renewable power plants and electricity capacity with the priority of investment of non-government sectors [58]. 
Table 12. RE policies in Iran extracted from upstream documents.

\begin{tabular}{|c|c|c|c|}
\hline Themes & Phrase & Frequency & Total Extracted Code in Themes \\
\hline \multirow{10}{*}{ International cooperation } & Development of electricity regional exchange & & \multirow{10}{*}{10} \\
\hline & $\begin{array}{l}\text { Participating in the development of } \\
\text { international standards }\end{array}$ & 1 & \\
\hline & Exploitation of foreign investment & 1 & \\
\hline & $\begin{array}{l}\text { Supporting companies in international } \\
\text { cooperation in renewable projects }\end{array}$ & 1 & \\
\hline & $\begin{array}{l}\text { Enactment of the law of Iran membership in } \\
\text { the International RE Agency }\end{array}$ & 1 & \\
\hline & $\begin{array}{l}\text { International cooperation development for } \\
\text { technology exchange }\end{array}$ & 1 & \\
\hline & $\begin{array}{l}\text { Enactment of the adhesion bill of the Islamic } \\
\text { Republic of Iran to the Kyoto Protocol }\end{array}$ & 1 & \\
\hline & $\begin{array}{l}\text { International interactions to attract experts in } \\
\text { the field of solar energy }\end{array}$ & 1 & \\
\hline & $\begin{array}{l}\text { Technology transfer and development with } \\
\text { increasing the international communication }\end{array}$ & 1 & \\
\hline & $\begin{array}{c}\text { Developing international cooperation with } \\
\text { region countries }\end{array}$ & 1 & \\
\hline
\end{tabular}

In 2011, the Energy Model Modification Act was passed, and Chapter 10 and Articles 61 and 62 of this law describe the application and investment in RE and nuclear energy. Based on this law, the Ministry of Energy should improve the extension of the use of RE resources [57]. To facilitate these issues, measures related to long-term contracts and guarantees for the purchase of non-governmental producers' renewable electricity can be taken by the relevant organization. The Ministries of Petroleum and also Energy should provide the required assistance to promote the economic use and support of RE resources separated from the network. For example, the Ministries of Petroleum provides publicly announced support for the extraction of gas from biomass resources and cost optimization in the supply and distribution of fossil fuels. Therefore, by 2021 (1400 Persian year), there have been some plans by the Ministry of Energy to enhance the capacity of production power and hydropower plants by $5 \%$. According to the plan, RE programs, on a small scale, have been started to create an incentive for the private sector to invest in power generation plans using wind, solar, mini-hydroelectric, and biomass energy [22]. In recent years, electricity power policies have led to the launching of 134 power plants for customers [57]. This has resulted in the generation of 5035 million $\mathrm{kWh}$ of electricity, a reduction of 468 million $\mathrm{kWh}$ of electricity network losses, 3417 thousand tons of $\mathrm{CO}_{2}$ emissions, and the elimination of 21.3 thousand tons of other pollutant sources [57]. In Iran, the efficiency and modification of energy structure can have a significant impact on the level of $\mathrm{CO}_{2}$ emissions [20]. Furthermore, it saves water $(1108 \mathrm{~mL})$, reduces unemployment by creating 31,271 jobs, and attracts 143.5 trillion IRR in non-governmental investment [15]. The construction of RE settlements will generate sources of revenue, reduce unemployment, and increase government tax revenues [15].

\section{Conclusions}

The results of the present study showed that Iran's current policies need to be reviewed, reformed, and strengthened. Therefore, to answer the first research question, it should be indicated that, due to the high dispersion of RE policies in Iran's five-year NDP, studying and analyzing this concept should be considered as a multifaceted issue. By resolving this issue, it will be much easier to assess the effectiveness of policies throughout the implementation and evaluation process. This helps reduce confusion amongst agencies 
and institutions while implementing and evaluating coherent policies. It also helps assess the success of these policies more simply in future research. Regarding the second research question, the investigation of how to expand the use of RE, especially for electricity generation in the world, showed that the leading countries in this sector (instead of using limited government funds to develop these resources) prepared the condition and opportunities for the non-governmental sector to invest in this sector. In leading RE countries, governments have succeeded in using the "strategic RE policy of guaranteed purchase" to activate and promote the market for this technology demand and, as a result, with the non-governmental sector investment, they will cause prosperity and development in the RE sector. In fact, RE strategic buy-back relates to policies that provide some guarantee mechanisms to RE private investors, such as "purchase guarantees" that ensure all REs have been purchased. Therefore, using these experiences, the guaranteed purchase policy in Iran should be updated in accordance with market changes, and its shortcomings should be eliminated so that it can play its role well.

In response to the third research question, the results show that the decentralization of policymaking in the unified organization is also one of the weaknesses in the policymaking process of renewables. The involvement of several institutions in policy development, policy implementation, price determination, price reform, etc., shows the interference and weakness of the policy system. Lack of applying the potential of the cooperative sector in the field of renewables was another issue that was criticized. The policy of setting up and strengthening RE cooperatives is an important step that needs to be strengthened.

To achieve comprehensive development, it is necessary to consider and identify all the available potentials, but this issue has not been observed in human resource development policies, and most policies focus on training and educating solar energy professionals and have ignored other energies. Indeed, there have not been enough studies in the field of RE policies in the world. The market issue is also in a weak position, and international cooperation in achieving and developing the market is weak. Considering the last research question, to develop RE, financial and legal tools, technology advancement, awarenessraising, capacity building, and training need special attention. These policies need to be explained to the public, especially to the governmental executive organizations and private and elite institutions. In other words, it is necessary to promote the adopted policies in accordance with the level of awareness of different groups of the society so that it becomes a common perspective for both executors and public.

In 2009 (1388 Persian year), the annual cost of energy subsidies for public use was about 442 thousand billion IRR. Macroeconomic indicators and food supplies are being undermined by high fuel prices, and better options must be created by the government to decrease public discontent. International agreements and environmental strategies such as the Kyoto and Paris Agreements highlight decreasing $\mathrm{CO}_{2}$ emissions. Iran is also a part of some of these agreements. However, there is a commitment to decrease $\mathrm{CO}_{2}$ emissions and prepare Iran's infrastructure for the adoption of clean energy. Although RE has the potential for growth in Iran because of environmental, social, and economic benefits, the study found that it may confront infrastructural, managerial, socio-cultural, and economic hurdles. To face these challenges, proactive and inventive policymaking is necessary. The overall outlook for these policies may be beneficial to some, such as installing solar panels in remote rural areas, but the overall outlook for these policies has been negative. The goal of Iran's five-year NDP is to raise the share of RE in electricity generation to 5\%. Moreover, based on the findings, the Renewable Energy and Energy Efficiency Organization indicated a significant delay in the purpose of the program. The decision to use more fossil fuels, particularly natural gas, is contradictory, given its lower environmental compatibility and the goal of decreasing greenhouse gas emissions, as well as decreasing energy security by relying on fossils resources. According to the current program's guidelines, developing RE resources can be a positive step, and a more active role in the development of potential RE such as biomass should be considered. For biomass exploitation, the implementation of exploitation methods can be extended to related government organizations such as SATBA, 
Energy Research Institute, metropolitan municipalities, and the Agricultural Research and Extension Organization.

Thus, in a country with abundant fossil fuel resources, proper policies and guidance are needed for the development of RE in the future and the reduction in international restrictions on the use of advanced technologies. Notable investment in RE at the local level requires the use of revenues from crude oil exports with great potential for a future without fossil fuels. Increasing public awareness, degrading subsidies for energy, and providing appropriate and significant incentives are essential to stimulate private investors.

Cheap fossil fuels and subsidies prevent serious operational actions to generate RE on a large scale, and as long as this problem persists, we cannot expect to replace fossil fuels with renewables. Therefore, it is expected that policy changes will take place in this regard. The rising exchange rates and sanctions act as a barrier to policy implementation. It is necessary to adopt policies to create and facilitate investment space for the development of RE polices for domestic and foreign investors. In the education policies section, it is necessary to consider all groups of the society, especially the rural people and male and female farmers who are dealing with energy. Adopting and reforming policies and using the experiences of other countries can be effective (e.g., realizing energy prices in Norway, setting up specialized laboratories in the field of renewable technologies in the United States, and introducing incentive tariffs to produce biofuels in Denmark).

\section{Policy Recommendations}

According to the findings of this study, the following policy considerations in the RE sector can be recommended:

- Addressing the four key objectives of the RE's strategic policy, i.e., energy security, financial advantages, social equity, and protecting the environment;

- Establishing an RE policy that integrates the use of the potential strengths of renewable energy sources with the GHG mitigation policy;

- Describing a priority-based policy for clean and green future energy project development;

- Strengthening facilities for investors in the private RE sector;

- Modifying the RE project legislation and licensing policies;

- Strengthening the country's stable political regime in order to facilitate both domestic and international investment; and

- Improving international cooperation by providing clear policy support that is resilient to management plan changes.

Finally, it can be concluded that Iran has the necessary and sufficient capacity to develop sustainable and clean RE policies. According to the results, fossil fuels are very important sources of heat and light. For this reason, in addition to crude oil exports, Iran is currently exploring and developing new oil reserves so that it can make the best use of these resources.

Due to the dispersion and frequency of different opinions in Iran's RE policies, research on policies to use RE and analysis of the documents have been associated with many problems. Therefore, it is suggested that this dispersion should be prevented in future studies by using an appropriate indicator or criterion such as the general sustainability indicator (GSI). By solving this issue, it will be much easier to examine the effectiveness of RE policies in the implementation and evaluation phases. This helps avoid confusion between agencies and institutions when implementing and evaluating coherent policies. It also assists in examining the effectiveness of these policies more easily, which could be addressed in future studies. Overall, in this study, the purpose was to review and analyze all the RE policies adopted in the Iranian program and documents. In fact, no information was available on the existence of some of these policies. In other words, it was not clear what policies had been adopted because no study had been conducted on the same topic due to the difficulty of the work. However, future studies could apply principal component analysis and investigate a fewer number of variables. 
Supplementary Materials: The following are available online at https:/ /www.mdpi.com/article/10 .3390 / su14031501/s1, Table S1: Name of upstream documents related to RE policies in Iran.

Author Contributions: Conceptualization, methodology, software, validation, formal analysis, investigation, resources, data curation and writing —original draft preparation, S.D.; supervision and project administration, S.C.; writing-review and editing, visualization, S.C.; B.G.; H.F.; A.-H.V.; H.I.S.; S.V.P. and H.A. All authors have read and agreed to the published version of the manuscript.

Funding: This research received no external funding.

Institutional Review Board Statement: Not applicable.

Informed Consent Statement: Not applicable.

Data Availability Statement: Raw data were generated at Tarbiat Modares University. We confirm that the data, models, and methodology used in the research are proprietary, and derived data supporting the findings of this study are available from the first author on request.

Conflicts of Interest: We have no known competing financial interests or personal relationships that could have appeared to influence the work reported in this paper.

\section{References}

1. Nachod, B.; Keller, E.; Hassanein, A.; Lansing, S. Assessment of petroleum-based plastic and bioplastics degradation using anaerobic digestion. Sustainability 2021, 13, 13295. [CrossRef]

2. Sun, Y.; Cao, C. The evolving relations between government agencies of innovation policymaking in emerging economies: A policy network approach and its application to the Chinese case. Res. Policy 2018, 47, 592-605. [CrossRef]

3. Schmid, T.S.; Sewerin, S. Measuring the temporal dynamics of policy mixes-An empirical analysis of renewable energy policy mixes' balance and design features in nine countries. Res. Policy 2018, 48, e103557. [CrossRef]

4. Malik, S.N.; Sukhera, O.R. Management of natural gas resources and search for alternative renewable energy resources: A case study of Pakistan. Renew. Sus. Energy Rev. 2012, 16, 1282-1290. [CrossRef]

5. Carley, S. State renewable energy electricity policies: An empirical evaluation of effectiveness. Energy Policy 2009, 37, 3071-3081. [CrossRef]

6. Bayulgen, O.; Benegal, S. Green priorities: How economic frames affect perceptions of renewable energy in the United States. Energy Res. Soc. Sci. 2019, 47, 28-36. [CrossRef]

7. Thapar, S.; Sharma, S.; Verma, A. Economic and environmental effectiveness of renewable energy policy instruments: Best practices from India. Renew. Sustain. Energy Rev. 2016, 66, 487-498. [CrossRef]

8. Jenner, S.; Groba, F.; Indvik, J. Assessing the strength and effectiveness of renewable electricity feed-in tariffs in European Union countries. Energy Policy 2013, 52, 385-401. [CrossRef]

9. Perea-Moreno, A.-J. Renewable energy and energy saving: Worldwide research trends. Sustainability 2021, 13, 13261. [CrossRef]

10. Griffiths, S. Renewable energy policy trends and recommendations for GCC countries. Energy Trans. 2017, 1, 3. [CrossRef]

11. Renn, O.; Marshall, J.P. Coal, nuclear and renewable energy policies in Germany: From the 1950s to the "Energiewende". Energy Policy 2016, 99, 224-232. [CrossRef]

12. Antoniou, F.; Strausz, R. The Effectiveness of Taxation and Feed-In Tariffs. CESifo Working Paper, No. 4788, Center for Economic Studies and ifo Institute (CESifo), Munich 2014. Available online: http:/ /hdl.handle.net/10419/96816 (accessed on 19 February 2021).

13. Rezaei, R.; Ghofranfarid, M. Rural households' renewable energy usage intention in Iran: Extending the unified theory of acceptance and use of technology. Renew. Energy 2018, 122, 382-391. [CrossRef]

14. Ravindranath, N.; Balachandra, P. Sustainable bioenergy for India: Technical, economic and policy analysis. Energy 2009, 34, 1003-1013. [CrossRef]

15. SATBA. Statistical Report of Iran's Renewable Energies in 2019 From Renewable Energy and Energy Efficiency Organization (SATBA). 2019. Available online: http:/ /www.satba.gov.ir/suna_content/media/image/2020/01/8026_orig.pdf (accessed on 19 February 2021).

16. Hemmati, M. A Sustainable Transition to Renewable Energy Resources in Oil Producing Countries: A Case Study of Iran. Master's Thesis, Lund University, Lund, Sweden, August 2017. Available online: https://lup.lub.lu.se/luur/download?func= downloadFile\&recordOId=8924486\&fileOId=8924488 (accessed on 19 February 2021).

17. Chaharsooghi, S.K.; Rezaei, M.; Alipour, M. Iran's energy scenarios on a 20-year vision. Int. J. Environ. Sci. Technol. 2015, 12, 3701-3718. [CrossRef]

18. Ghouchani, M.; Taji, M.; Cheheltani, A.S.; Chehr, M.S. Developing a perspective on the use of renewable energy in Iran. Technol. Forecast. Soc. Chang. 2021, 172, 121049. [CrossRef]

19. Noorolahi, Y.; Golshanfard, A.; Yousefi, H.; Ansaripour, S. The role of renewable energies on smart energy systems-A review. J. Renew. New Energy 2020, 7, 81-86. 
20. Solaymani, S. A CO 2 emissions assessment of the green economy in Iran. Greenh. Gases Sci. Technol. 2020, 10, 390-407. [CrossRef]

21. Aryanpur, V.; Atabaki, M.S.; Marzband, M.; Siano, M.P.; Ghayoumi, K. An overview of energy planning in Iran and transition pathways towards sustainable electricity supply sector. Renew. Sustain. Energy Rev. 2019, 112, 58-74. [CrossRef]

22. Shahsavari, A.; Yousefi, H.; Shahveran, E. The share of solar energy from the world energy basket in 2030. J. Renew. Innovat. Energ. 2018, 5, 116-121.

23. Razavieh, A.; Sedaghat, A.; Ayodele, R.; Mostafaeipour, A. Worldwide wind energy status and the characteristics of wind energy in Iran, case study: The province of Sistan and Baluchestan. Int. J. Sustain. Energy 2017, 36, 103-123. [CrossRef]

24. Aghahosseini, A.; Bogdanov, D.; Ghorbani, N.; Breyer, C. Analysis of 100\% renewable energy for Iran in 2030: Integrating solar PV, wind energy and storage. Int. J. Environ. Sci. Technol. 2018, 15, 17-36. [CrossRef]

25. Mollahosseinia, A.; Hosseinib, S.A.; Jabbaric, M.; Figolid, A.; Rahimpour, A. Renewable energy management and market in Iran: A holistic review on current state and future demands. Renew. Sustain. Energy Rev. 2017, 88, 774-788. [CrossRef]

26. Ghasemi, A.; Taklif, A.; Mohammadi, T.; Mohammadian, F. Analysis of Iran's energy strategies on the horizon of 2041 in the framework of global energy scenarios. Iran. J. Energy Econ. 2017, 6, 121-189.

27. Aized, T.; Shahid, M.; Bhatti, A.A.; Saleem, M.; Anandarajah, G. Energy security and renewable energy policy analysis of Pakistan. Renew. Sustain. Energy Rev. 2018, 84, 155-169. [CrossRef]

28. Chang, Y.; Fang, Z.; Li, Y. Renewable energy policies in promoting financing and investment among the East Asia Summit countries: Quantitative assessment and policy implications. Energy Policy 2016, 95, 427-436. [CrossRef]

29. Rachmawatie, D.; Rustiadi, E.; Fauzi, A.; Juanda, B. Empowerment of rural community through the development of renewable electricity. J. Perspektif Pembiayaan Dan Pembangunan Daerah 2020, 8, 139-154. [CrossRef]

30. Zhou, S.; Solomon, B.D. Do renewable portfolio standards in the United States stunt renewable electricity development beyond mandatory targets? Energy Policy 2020, 140, 111377. [CrossRef]

31. Grassi, M.C.B.; Pereira, G.A.G. Energy-cane and RenovaBio: Brazilian vectors to boost the development of Biofuels. Ind. Crop. Prod. 2019, 129, 201-205. [CrossRef]

32. Sajid, Z.; Silva, M.A.B.D.; Danial, S.N. Historical analysis of the role of governance systems in the sustainable development of biofuels in Brazil and the United States of America (USA). Sustainability 2021, 13, 6881. [CrossRef]

33. Jarke, J.; Perino, G. Do renewable energy policies reduce carbon emissions? On caps and inter-industry leakage. J. Environ. Econ. Manag. 2017, 84, 102-124. [CrossRef]

34. García-Olivares, A.; Solé, J.; Osychenko, O. Transportation in a 100\% renewable energy system. Energy Conv. Manag. 2018, 158, 266-285. [CrossRef]

35. Haseeb, M.; Abidin, I.S.Z.; Hye, Q.M.A.; Hartani, N.H. The impact of renewable energy on economic well-being of Malaysia: Fresh evidence from auto regressive distributed lag bound testing approach. Int. J. Energy Econ. Policy 2019, 9, 269.

36. Guzowski, C.; Recalde, M. Renewable energy in Argentina: Energy policy analysis and perspectives. Int. J. Hydrogen Energy 2008, 33, 3592-3595. [CrossRef]

37. Onifade, T.T. Hybrid renewable energy support policy in the power sector: The contracts for difference and capacity market case study. Energy Policy 2016, 95, 390-401. [CrossRef]

38. Zervas, E.; Vatikiotis, L.; Gareiou, Z.; Manika, S.; Herrero-Martin, R. Assessment of the Greek National Plan of Energy and Climate Change-Critical remarks. Sustainability 2021, 13, 13143. [CrossRef]

39. Müller, B.C.; Kühn, S.; van Baaren, R.B.; Dotsch, R.; Brass, M.; Dijksterhuis, A. Perspective taking eliminates differences in co-representation of out-group members' actions. Exp. Brain Res. 2011, 211, 423-428. [CrossRef]

40. Stokes, S.C.; Dunning, T.; Nazareno, M.; Brusco, V. Brokers, Voters, and Clientelism: The Puzzle of Distributive Politics; Cambridge University Press: Cambridge, UK, 2013.

41. Horschig, T.; Thrän, D. Are decisions well supported for the energy transition? A review on modeling approaches for renewable energy policy evaluation. Energy Sustain. Soc. 2017, 7, 5. [CrossRef]

42. Gielen, D.; Boshell, F.; Saygin, D.; Bazilian, M.D.; Wagner, N.; Gorini, R. The role of renewable energy in the global energy transformation. Energy Strategy Rev. 2019, 24, 38-50. [CrossRef]

43. Shrimali, R.K.; Ahmad, S.; Verma, V.; Zeng, P.; Ananth, S.; Gaur, P.; Khleif, S.N. Concurrent PD-1 blockade negates the effects of OX40 agonist antibody in combination immunotherapy through inducing T-cell apoptosis. Cancer Immunol. Res. 2017, 5, 755-766. [CrossRef]

44. Mamat, R.; Sani, M.S.M.; Sudhakar, K.; Kadarohman, A.; Sardjono, R.E. An overview of higher alcohol and biodiesel as alternative fuels in engines. Energy Rep. 2019, 5, 467-479.

45. Bulut, U.; Muratoglu, G. Renewable energy in Turkey: Great potential, low but increasing utilization, and an empirical analysis on renewable energy-growth nexus. Energy Policy 2018, 123, 240-250. [CrossRef]

46. Argentiero, A.; De Summa, S.; Di Fonte, R.; Iacobazzi, R.M.; Porcelli, L.; Da Vià, M.; Brunetti, O.; Azzariti, A.; Silvestris, N.; Solimando, A.G. expression comparison between the lymph node-positive and-negative reveals a peculiar immune microenvironment signature and a theranostic role for WNT targeting in pancreatic ductal adenocarcinoma: A pilot study. Cancers 2019, 11, 942. [CrossRef] [PubMed]

47. Babich, V.; Lobel, R.; Yücel, Ş. Promoting solar panel investments: Feed-in-tariff vs. tax-rebate policies. Manuf. Serv. Operat. Manag. 2020, 22, 1148-1164. [CrossRef] 
48. Ndiritu, S.W.; Engola, M.K. The effectiveness of feed-in-tariff policy in promoting power generation from renewable energy in Kenya. Renew. Energy 2020, 161, 593-605. [CrossRef]

49. Cui, G.; Wang, W.; Dou, B.; Liu, Y.; Tian, H.; Zheng, J.; Liu, Y. Geothermal energy exploitation and power generation via a single vertical well combined with hydraulic fracturing. J. Energy Eng. 2022, 148, 04021058. [CrossRef]

50. Cui, G.; Ning, F.; Dou, B.; Li, T.; Zhou, Q. Particle migration and formation damage during geothermal exploitation from weakly consolidated sandstone reservoirs via water and $\mathrm{CO}_{2}$ recycling. Energy 2021, 240, 122507. [CrossRef]

51. Taghizadeh-Alisaraei, A.; Assar, H.A.; Ghobadian, B.; Motevali, A. Potential of biofuel production from pistachio waste in Iran. Renew. Sustain. Energy Rev. 2017, 72, 510-522. [CrossRef]

52. Solaymani, S. A review on energy and renewable energy policies in Iran. Sustainability 2021, 13, 7328. [CrossRef]

53. Dehhaghi, S.; Choobchian, S. The role of photovoltaic water pumps in development of agricultural sector. J. Sol. Energy Res. 2017, 2, 281-285.

54. Islamic Parliament Research Center Report. Retrieved 2019 from Islamic Parliament Research Center of the Islamic Republic of Iran. 2014. Available online: https:/ / rc.majlis.ir/fa/news/show/892392 (accessed on 7 February 2019).

55. Energy Balance Sheet. Retrieved 2019 from Ministry of Power. 2019. Available online: http://pep.moe.gov.ir/getattachment (accessed on 3 March 2019).

56. Chen, L.; Naughton, B. An institutionalized policy-making mechanism: China's return to techno-industrial policy. Res. Policy 2016, 45, 2138-2152. [CrossRef]

57. Ministry of Energy. Energy Statistics and Charts of Iran and the World 2017; Ministry of Energy: Tehran, Iran, 2020.

58. Mobini, H.; Haghifam, M.R. Opportunities and obstacles in utilizing the renewable electric power resources in Iran. Int. J. Smart Electr. Eng. 2021, 10, 1-6. 